\title{
Evolutions of Employment and Turnover in Services in EU
}

Article history:

Received:26 March 2014

Sent for revision:15 April 2014

Received in revised form: 26 May 2014

Accepted: 3 June 2014

Available online: 1 July 2014

\begin{abstract}
Since the mid-twentieth century services have become a vital economic sector of modern economies. Creating and EU enlargement has boosted strong so-called third sector. Although the general trend in the EU is the convergence, different levels of development and economic crisis of recent years have led to various developments in this sector. This paper presents an analysis of the evolution of services both in the EU and some member states such as Romania, in terms of turnover indices in services and labor input in services during 2003-2012. It also analyzes the correlations between the changes in turnover and the changes in number of employees in this sector.
\end{abstract}

Keywords: Economic; Services; Employment; Turnover.

\section{Kretanje zaposlenosti i prometa u uslužnom sektoru EU}

Apstrakt: Od sredine dvadesetog veka usluge su postale vitalni ekonomski sektor u savremenim privredama. Stvaranje i proširenje EU je snožno uticalo na povećanje takozvanog trećeg sektora. lako je konvergencija opšti trend u EU, različiti nivoi razvoja i ekonomske krize u poslednjih nekoliko godina doveli su do različitih dešavanja u ovom sektoru. Ovaj rad predstavlja analizu sektora usluga u EU i nekim pojedinim zemaljama članicama, kao što je Rumunija, u smislu indeksa prometa robe u usluga i inputa rada u uslužnom sektoru u periodu 2003-2012. Takođe se analizira korelacija između promena u prometu i promene u broju zaposlenih u ovom sektoru.

Ključne reči: Ekonomija, servis, zaposlenost, promet.

\footnotetext{
${ }_{1}^{1}$ Petroleum-Gas University, Ploiesti, Romania, marianzaharia53@gmail.com

2 Petroleum-Gas University, Ploiesti, Romania

3 "Constantin Brancusi" University, Targu Jiu, Romania
} 


\section{Literature review}

Services through their characteristics and in particular because immateriality, unsustainable and lack of property were recognized later in the late eighteenth and early nineteenth century, as economic activities producing value. That, and because of their diversity and heterogeneity made it difficult to find a definition. Seem conclusive in this respect is Tordjman's definition that the service is an "element of the marketing company designed to provide additional utility product or trading unit" (Tordjman, 1987) and the definition of Ecalle "services are those economic activities are not manufacturing, or mining or agriculture "( Ecalle, 1989).

A highlight is the 70's of last century when the average growth rate of GDP created in the service is superior to other sectors. This rollover contribution led to the transformation of services, from a sector that hinders economic growth in a truly stimulating motor.

Thus, the services are beginning to know two development processes, one by longitudinal ascending, its role in economic growth and employment being increasingly higher, and one transversely, of diversification, becomes present in all sectors. From the methodological point of view these developments have made and still make it difficult to define their exhaustive (Ghibuţiu, 2000; Ioncică, 2000; Cristureanu, 2004). Also are used, both theoretical and practical, classifications of services, as criteria defined in different ways as: the nature of relationships with customers, the level of customization, flexibility of supply, delivery methods, performance characteristics (Lovelok, 1983)

Today, unprecedented diversity of human needs, the strong development of ICT and globalization highlights the key role of services, creating a circumstance which opens a passage to the strategic management of services. Effective implementation of globalization "can contribute to the progress of developing countries, but also developed ones" (Stiglitz, 2008). In these circumstances successful economies tend to be sophisticated both in production and services (Young, 2008)

Economic crisis triggered in 2009 was materialized in an unprecedented decline in transactions carried out both at intra-EU and extra-EU, both in goods and services and international flows. Marelli \& Signorelli (2010) identify growth models which were applied in EU during last two decades differing NMS and old members.

On the other hand, the creation and the continuous expansion of the European Union, after Croatia's accession on 1 July 2013, includes 28 members (EU28), offers new service development perspective for the fundamental sector of the modern world. In the European context, for a sustainable develop- 
ment, the process of developing of services will move increasingly to the individual to health, education and social protection.

\section{Research methodology}

In the analysis were chosen 12 countries (Bulgaria, Germany, Estonia, Greece, Spain, France, Croatia, Latvia, Lithuania, Hungary, Austria and Romania) and UE28 as a whole. Selection criteria were: the level of development and specificity indicators evolution used.

The data series used were taken from the Eurostat database http://epp.eurostat.ec.europa.eu/portal/page/portal/statistics/search_database.

Methodologically, the paper is based on statistical analysis methods presented in the works of Jaba (1998) and of Gogonea (2006), and on econometric methods for testing of statistical hypothesis (Jaba \& Grama, 2004; Labar, 2008; Zaharia \& Gogonea, 2008).

To analyze the time evolution of the two indicators (turnover and employment in services) from their empirical values $y_{i}, i=\overline{1, n}$, were used graphical method, average growth method

$$
\bar{\Delta}=\frac{\sum_{i=2}^{n} \Delta_{i / i-1}}{n}
$$

where $\Delta_{i / i-1}$ is the chain based annual growth $\left(\Delta_{i / i-1}=y_{i}-y_{i-1}\right)$ and the average rate method

$$
\bar{R}=\sqrt[n]{\prod_{i=2}^{n} R_{i / i-1}}
$$

where $R_{i / i-1}$ is the chain based annual rate $\left(R_{i / i-1}=y_{i} / y_{i-1}\right)$.

To analyze the correlation between turnover and employment in services was used Multiple R:

Multiple_R $R=\sqrt{\frac{\Delta_{y / x}^{2}}{\Delta_{y}^{2}}}=\sqrt{\frac{\sum_{i=1}^{n}\left(\hat{y}_{i}-\bar{y}\right)^{2}}{\sum_{i=1}^{n}\left(y_{i}-\bar{y}\right)^{2}}}$ 
where $\Delta_{y}^{2}$ represents the overall variance (variance of the variable $y$ in relation to the average of all empirical values) and $\Delta_{y / x}^{2}$ is the average variance towards their theoretical values

Statistical significance testing was performed using the $F$ test (FisherSnedecor) the statistic test is:

$$
F_{c}=\frac{\text { R_Square }}{1-\mathrm{R} \_ \text {Square }} \cdot \frac{n-k-1}{k}
$$

where, in this case, $k=1$.

As IT support in processing and data analysis were used SPSS.

\section{Results and discussion}

The impact of economic crisis on services in the EU countries, had developments and different intensities determined by the levels of development and policies applied both in the period before crisis and during the course of it. The general trend is of convergence, however.

\subsection{Evolutions in Turnover of Services in EU28}

In the period before the economic crisis, both in the EU27 as well as in the country, turnover derived from activities (Services required by STS regulation (except retail trade and repair)), experienced continuous growth (Figure 1). Thus, while the EU28 average, compared to 2010 , recording $78.17 \%$ in 2003 and $105.67 \%$ in 2008 (27.5 percentage points), in Romania, the evolution of turnover of services (Turnover in services), showed a trend much stronger, from $41.54 \%$ in 2003 to $118.56 \%$ in 2010 and by 77.02 percentage points. Of the countries surveyed in 2003 were, along with Romania, below the UE28, Hungary, Lithuania and Bulgaria, countries where this indicator will exceed the European average in 2006, 2007 (Lithuania) and 2008 (Bulgaria).

Above EU28 average were Greece, Croatia and Germany. Note that the developed countries like Germany or France, between 2003 and 2008, were very close to the average EU28. Hungary also was also close to the average EU28. Croatia and Greece have been somewhat higher values in turnover compared to the level recorded in 2010. Thus, in 2008 Croatia value of this indicator was $124.09 \%$ and in Greece was $131.51 \%$ (the highest value recorded). 
The crisis in 2009 has undoubtedly affected the economies of all the states of Europe and therefore the turnover recorded in services. Intensities, however, were much different. While in Austria in 2009 the turnover of the services was down by 6.73 percentage points and 6.71 percentage points in Hungary, namely Germany 11.91 percentage points, other countries were more pronounced reductions. In Latvia the turnover recorded in services in 2009 was only $68.57 \%$ compared to 2008 , Lithuania $71.14 \%$ and $78.76 \%$ in Estonia. In Romania the turnover recorded in services in 2009 was $83.90 \%$ compared with the level in 2008. Similar declines were registered in Spain (84.84\%), Greece $(87.61 \%)$ and Bulgaria $(87,53 \%)$.

Figure 1. Evolution of turnover of services in EU28 countries $(2010=100)$

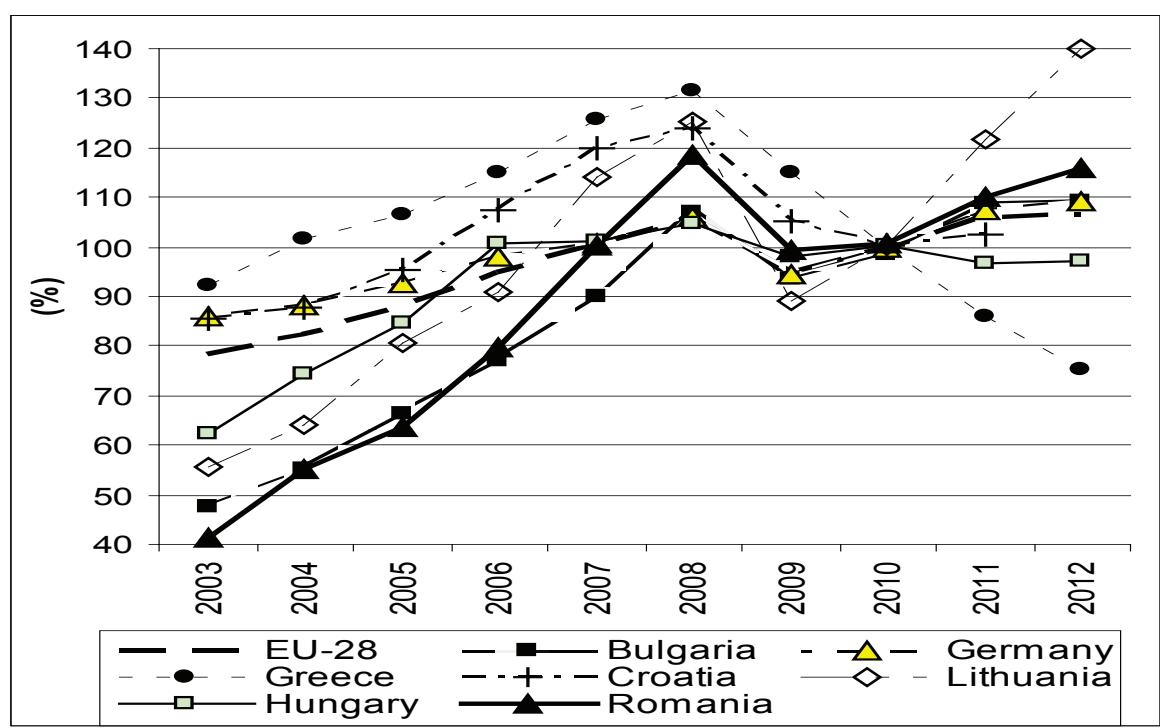

Source: own construction

If during the debut of the crisis the impact on services turnover recorded was similar in Europe, developments in the period 2010 - 2012 are much different. In countries such as Lithuania, Latvia and Estonia, although the impact was stronger in the period 2010 - 2012 the return was equally significant. Level of turnover indices registered in services in 2012 compared to 2010 was $140.04 \%$ in Lithuania, in Latvia to $137.80 \%$ and $130.7 \%$ respectively in Estonia. Note that in all three countries in 2012 have exceeded the levels recorded in 2008 , before the onset of the crisis with $11.95 \%$ in Lithuania, $11.60 \%$ in Estonia and $8.54 \%$ to Latvia. 
Given the level of development and volume activities were recorded in 2012 compared with 2010, recovery of turnover in services in Germany (109.20\%), France $(107.93 \%)$ and Austria $(105.71 \%)$. And if in these countries turnover of service levels exceeded 2008 levels by $2.85 \%$ in Germany, 4.58\% in France and $4.91 \%$ in Austria.

Significant increases above the average UE28 (106.61\%) were recorded in this indicator also in Romania (115.95\%) and Bulgaria (109.26\%). Note, however, that if in Bulgaria the turnover of registered services in 2012 is $2.00 \%$ higher than in 2008, in Romania's case it is only $92.69 \%$ from the level recorded in 2008. Consequently, in Romania, service industries have not yet overcome the economic crisis.

In some countries the impact of the economic crisis on services was so strong that even in 2012 could not reach the level recorded in 2010. Hungary mention here that the turnover of services in 2012 was $97.07 \%$ and $92.69 \%$ from 2010 to 2008. Also in Spain is maintained service industries decline if the turnover of registered service in 2011 was $99.12 \%$ compared to 2010 , in 2012 it continues to decline reaching $92.36 \%$ compared to 2010 respectively $78.97 \%$ of 2008 level. A dramatic situation is in Greece. Here, the turnover of services decreased from the level recorded in 2010 to $86.15 \%$ in 2011 at $75.22 \%$ in 2012 respectively. In relation to the level recorded before the start of the economic crisis, the turnover of services in 2012 reached only $57.20 \%$.

To highlight the impact of the economic crisis on services, Table 1 shows turnover percentage change in services compared to corresponding period of the previous year. As was noted above, the impact and how analyzed countries have responded to the crisis differ significantly.

As can be seen, the crisis has affected all economies, and therefore the European average in 2009 to a decline of $10.2 \%$. But the crisis had a greater impact on many countries of the EU28. Thus, Lithuania, Latvia, and Estonia decline in services turnover was over $20 \%$ in the first year of the crisis.

With all the negative impact that the economic crisis has had on services in 2009, with two exceptions (Croatia and Greece which still recorded negative revolutions) of the countries analyzed in 2010 began the process of recovery, which for some of them (Bulgaria, Germany, Estonia, Lithuania and Latvia, France) was amplified in 2011. Unfortunately in 2011 were revived aspects of the economic crisis, so that a new turnover decline in services record in Hungary $(-3.50 \%$ compared to 2010$)$ and Spain $(-0.90 \%$ compared to 2010$)$. 
Table 1. Turnover in services percentage change compared to corresponding period of the previous year

\begin{tabular}{|l|r|r|r|r|}
\hline GEO/TIME & 2009 & & 2011 & 2012 \\
\hline EU-28 & -10.2 & 5.4 & 6.0 & 0.6 \\
\hline Bulgaria & -12.5 & 5.0 & 10.4 & 0.5 \\
\hline Germany & -11.2 & 6.1 & 7.6 & 1.5 \\
\hline Estonia & -21.2 & 8.6 & 17.8 & 10.7 \\
\hline Greece & -12.4 & -13.2 & -13.8 & -12.7 \\
\hline Spain & -15.2 & 0.8 & -0.9 & -6.8 \\
\hline France & -7.1 & 4.3 & 6.3 & 1.5 \\
\hline Croatia & -15.1 & -5.0 & 2.6 & $\#$ \\
\hline Latvia & -31.4 & 15.0 & 22.5 & 12.4 \\
\hline Lithuania & -28.9 & 12.5 & 21.6 & 15.1 \\
\hline Hungary & -6.4 & 2.1 & -3.5 & 0.5 \\
\hline Austria & -6.7 & 6.3 & 5.0 & 0.7 \\
\hline Romania & -16.1 & 1.2 & 9.2 & 5.5 \\
\hline
\end{tabular}

\# not available

Source:http://epp.eurostat.ec.europa.eu/portal/page/portal/statistics/search database

A more difficult situation is in Greece where the decline in 2011 is $13.80 \%$ compared to 2010 (record lows UE28). Year 2012 brings a flattening of the rate of recovery services, growth of turnover in the sector recorded growth compared to 2011, but with lower absolute values in Bulgaria, Germany, Estonia, France, Lithuania, Latvia, Austria and Romania. It should be emphasized, however, that growth rates from $0.6 \%$ to EU28, $0.5 \%$ in Bulgaria, 0.7 in Hungary, $1.5 \%$ in Germany and France, countries like Estonia, Lithuania and Latvia were registered in 2012 annual growth rates of turnover in service more than 10 times higher (15.10\% Lithuania, Latvia 12.40\%, Estonia 10.70\%). Meanwhile, in Romania, the growth rate of services turnover in 2012 was $5.50 \%$ compared to $9.20 \%$ in 2011 .

A special case with a continuous decline in the annual growth of turnover in services is recorded in Spain, $-0.9 \%$ to 2011 , or $-6.8 \%$ in 2012 and Greece, where the situation has become dramatic, and the annual rate growth of turnover in services continues to be significantly large negative values, $-13.80 \%$ in 2011 compared to 2010 and $-12.70 \%$ in 2012 compared to 2011 . It is obvious that in countries such as Spain and especially Greece situation has become critical. 


\subsection{Evolutions of Employment in Services in EU28}

During 2003-2008, in most countries the trend has been to increase the number of employees in services (Figure 2). Among the countries surveyed the most significant increase was in Bulgaria that in 2008 were employed in services with $45.62 \%$ more than in 2003 . Also significant increases were registered in Lithuania with $26.21 \%$ and Hungary with $22.23 \%$.

In Romania, the number of employees in services in 2008 was $16.28 \%$ higher than in 2003. Increases above the European average (6.39\%) are also in Estonia $(11.48 \%)$, Croatia $(11.30 \%)$, and Austria $(10.01 \%)$. Finally, in countries like Germany, France and Greece, from 2003-2008 the number of employees in services remained approximately constant.

On the other hand, have pointed out that development in the period 2003 2008 were not linear, annual rates of evolution of the number of employees in services differ significantly. Moreover, the maximum and minimum values thereof are not synchronized in time so that in all countries of EU28 it compensates each other (Figure 3). Due to this, the EU during 2003-2007 increased almost linearly from $0.3 \%$ in 2003 to $3.0 \%$ in 2007 .

Figure 2. Index evolution number of employees services in EU28 countries $(2010=100)$

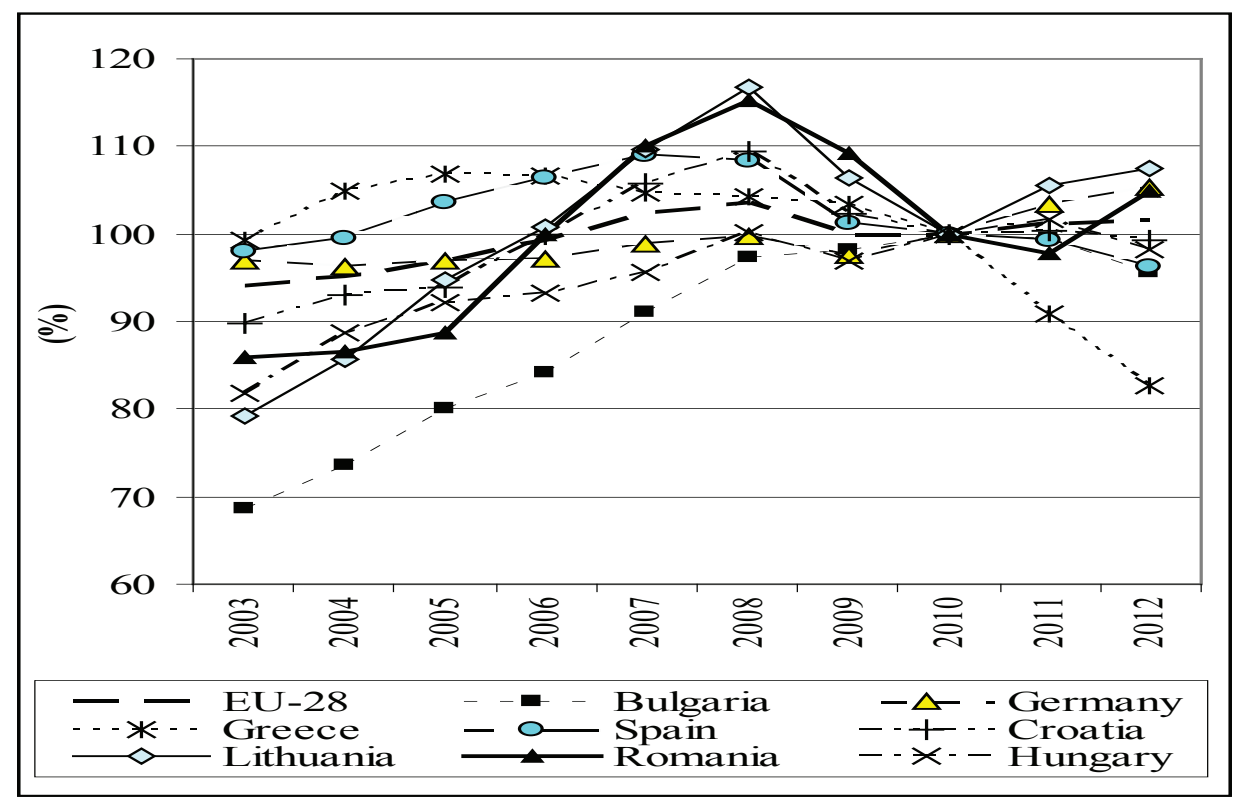

Source: own construction 
In 2004, while the annual growth rate of employees in service levels peak period in Latvia (12.9\%) and Hungary $(8.4 \%)$, in others they were minimum values corresponding to period $(0.6 \%$ in France, $0.7 \%$ in Romania and $-0.8 \%$ in Germany). In 2005, while in Spain and Lithuania there were specific maximum value $(4.3 \%$ in Spain and $10.5 \%$ in Lithuania) in Croatia reached minimum of period $(1.0 \%)$.

In the countries surveyed, most high annual growth rates of employees in services recorded in 2007 and 2008. Thus, Romania in 2007 its value was $12.6 \%$ and in 2008 there were annual rates above $8 \%$ in Bulgaria $(8.2 \%)$, Estonia (9.9\%), Latvia (12.2\%), Lithuania (8.6\%) and Romania (10.1\%). A special situation is in Greece, after the maximum of $5.5 \%$ in 2004 , followed by $2.0 \%$ in 2005 , almost three years before the onset of the crisis begin reducing the number of employees in this sector.

Figure 3. Evolution of the annual rate of the number of employees in services in some countries of the EU28

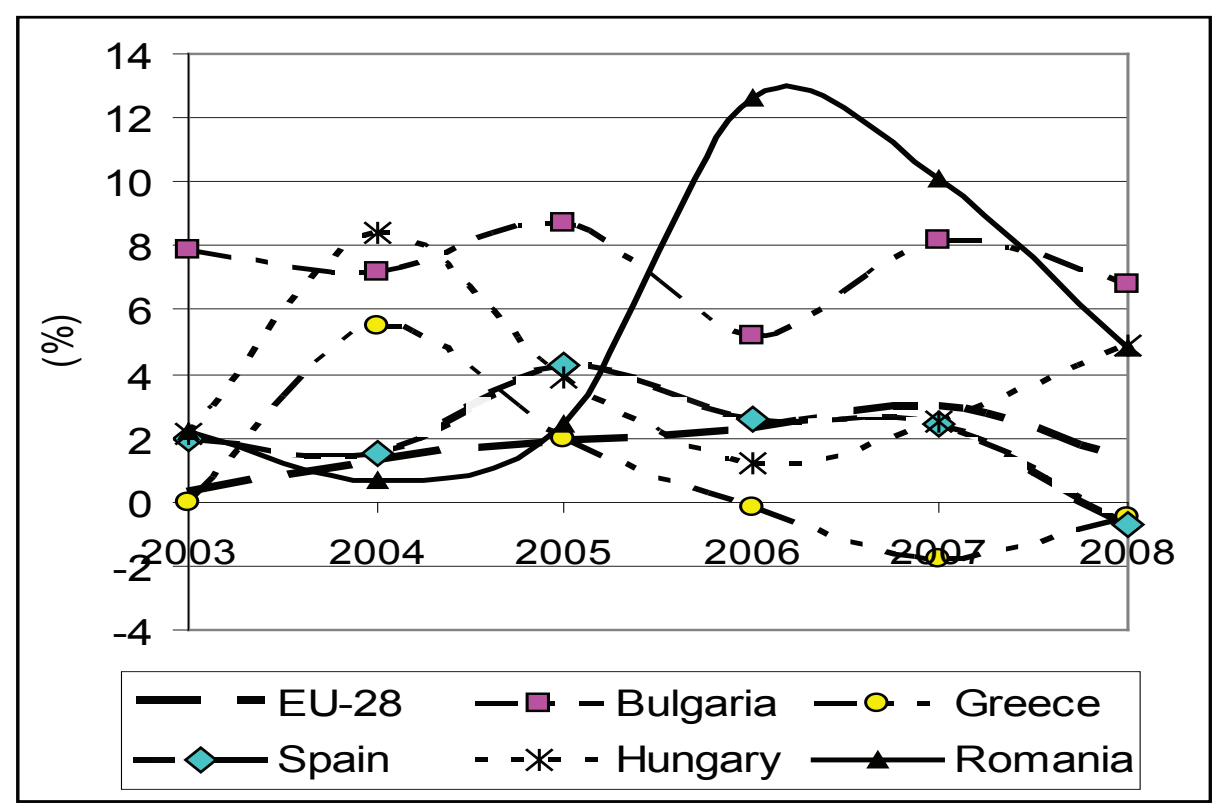

Source: own construction

Since 2008, annual growth of the number of employees in the service of all the countries analyzed decreases significantly. While in some countries registered annual growth rates still have relatively high values (Bulgaria 6.8\%, 
Lithuania $6.4 \%$, Hungary $4.9 \%$ and Romania $4.8 \%$ ), in others develop or maintain negative rates (Greece: $-0.5 \%$, Spain $-0.7 \%$ and Latvia: $-1.2 \%$ ).

The economic crisis started after 2008 has strong influences in the number of people employed in services. However, they are different from country to country. In the EU28 services sector recession was impressive only in 2009, when the number of employees in services decreased by $3.6 \%$, after which there is a slight recovery, the pace becomes slightly positive. A similar situation is recorded in Germany and Austria, where in 2009 the number of employees in services decreased by $2.2 \%$, after which it recorded significant positive rates $(2.5 \%$ in 2010 and $3.4 \%$ in 2011 in Germany and $2.5 \%$ in 2011 in Austria ) by the end of the review period. Also in France and Hungary after the 2009 recession that employment in services decreased by $2.9 \%$ and $3.3 \%$, following a period of recovery, but we make cuts in $2012:-0.3 \%$ in France and $-3.3 \%$ in Hungary .

In Estonia, Lithuania and Latvia, crisis services sector remains large layoffs two years in $2009(-11.3 \%$ in Estonia, $-17.9 \%$ to $-8.8 \%$ in Latvia and Lithuania). 2011 and 2012 brought a revival of services but the number of employees in this sector increased at rates ranging in 2011 from 5.6\% in Lithuania and 3.5\% in Estonia, and in 2012 from 1.7\% in Lithuania and 8.6\% in Latvia.

Different situations are registered in Bulgaria, Greece and Romania. Thus, in Bulgaria in the early years of the crisis the number of employees in services continued to increase $(1.0 \%$ in 2009 and $1.7 \%$ in 2010) due to strong growth in coastal development services and in ski resorts. The economic crisis in Europe has spread also here, bringing in 2012 to $4.0 \%$ dismissal of employees in services.

In Romania, the impact of the economic crisis on services remained three years with significant reduction of employees in this sector. After a decrease in 2009 to $5.3 \%$ of employees in service in 2010 crisis is increasing leading to fewer employees in this sector by another $8.4 \%$ continuous decline in 2011 ($2.2 \%$ ). Recovery feels only in 2012 the demand for labor in increasing the service begins to grow by $7.3 \%$ in the number of employees compared to 2011.

Finally, in Greece, the economic crisis and the services was particularly high. The continuous decrease in turnover in service to this country, as was pointed out above and as shown in Table 1, was and is accompanied by drastic reduction of employees in services. Their numbers began to decline relatively easy since 2006 and $2007(-1.8 \%)$, reaching values of increasingly unfavorable $(-9.2 \%$ in 2011 and $-9.0 \%$ in 2012$)$. 


\subsection{Quantitative Issues Regarding the Correlation Between Annual Turnover and Employees in Services}

In this chapter we set out to determine whether between annual rates of population turnover and employed in services are correlations and if so, what is the direction and intensity. Assumptions are:

$H_{0}$ : Developments in annual rates of turnover from tourism is not significantly influenced by developments in rhythms number of employees in tourism

$H_{1}$ : Developments in annual rates of turnover from tourism rates are significantly influenced by the number of employees in tourism developments

The results of tests for significance level (probability of 95\%) are shown in Table 2. The condition of acceptance of the hypothesis HO is Significance_F $<0.05$.

Table 2 - Results of testing hypotheses on correlations between evolution of annual rates of turnover and number of employees in service during 20032012

\begin{tabular}{|l|r|r|r|l|}
\hline & Multiple_R & R_Square & Significance $F$ & $\mathrm{H}_{0}$ Hypothesis \\
\hline EU-28 & 0.932 & 0.868 & 0.000 & Rejected \\
\hline Bulgaria & 0.699 & 0.489 & 0.024 & Rejected \\
\hline Germany & 0.746 & 0.557 & 0.013 & Rejected \\
\hline Estonia & 0.871 & 0.758 & 0.001 & Rejected \\
\hline Greece & 0.751 & 0.563 & 0.012 & Rejected \\
\hline Spain & 0.965 & 0.931 & 0.000 & Rejected \\
\hline France & 0.950 & 0.902 & 0.000 & Rejected \\
\hline Croatia & 0.917 & 0.841 & 0.000 & Rejected \\
\hline Latvia & 0.786 & 0.618 & 0.007 & Rejected \\
\hline Lithuania & 0.770 & 0.593 & 0.009 & Rejected \\
\hline Hungary & 0.535 & 0.286 & 0.111 & Accepted \\
\hline Austria & 0.920 & 0.847 & 0.000 & Rejected \\
\hline Romania & 0.515 & 0.265 & 0.128 & Accepted \\
\hline
\end{tabular}

Source: own determinations 
As shown in Table 2, in most countries analyzed, the hypothesis $\mathrm{H}_{0}$ is rejected and $\mathrm{H}_{1}$ hypothesis is accepted. The general conclusion is that in the period under review there were correlations between the two indicators and therefore their policies on services both in the period before and after the economic crisis were consistent with the characteristics of those countries and market developments services.

In the case of Hungary and Romania $\mathrm{H}_{0}$ hypothesis is accepted which means that developments in tourism turnover in these countries were mainly influenced by other factors. One conclusion to be drawn here is that, in both countries, there has been a rapid adaptation to market requirements, our staff number is consistent with the volume of activities in this sector.

In the countries where the hypothesis $\mathrm{H}_{0}$ is rejected and $\mathrm{H}_{1}$ hypothesis is accepted, the values recorded by Multiple_R highlights the correlation between the percentage of indicators examined and R_Square highlights trends in the number of employees influence the evolution of turnover in services.

The evidence that at the level of EU28 countries, correlation ratio is set to 0932, the links between the two indexes are very strong. High values of the correlation ratio (corresponding to strong correlations) of indicators examined were recorded in Spain (0965), France (0.95), Croatia (0917), Austria (0.92) and Estonia (0871).

Although lower values (ranging between 0.699 and 0.786 ) of the ratio of the correlation between evolutions in turnover and evolutions of the share of services in countries such as Bulgaria, Germany, Greece, Lithuania and Latvia, the percentage trends in the number of employees influence the evolution of annual sales in services ranges from a minimum of $48.9 \%$ in Bulgaria and a maximum of $61.8 \%$ in Latvia.

Regarding Romania and Hungary, according to the hypothesis $\mathrm{HO}$ developments in annual rates of turnover from tourism evolutions are not significantly influenced by the number of employees in tourism rates, conditions in which the values recorded by Multiple_R and R_Square not statistically significant and can not be interpreter.

\section{Conclusions}

Continued expansion of the European Union (EU28) offers new service development perspective as fundamental sector of the modern world. Economic crisis started in late 2008 still marks the third sector evolutions in the EU even more as the member countries have different development levels, but the overall trend is convergence. In the period before the economic crisis, both in the EU27 and in the country, turnover derived from activities (Services re- 
quired by STS regulation (except retail trade and repair)), experienced continuous growth.

The crisis in 2009 has undoubtedly affected all European economies and consequently the turnover recorded in service but with very different intensities. In some countries the impact of the economic crisis on services was so strong that even in 2012 could not reach the level recorded in 2010 (Hungary). A special case with a continuous decline in the annual growth of turnover in services is recorded in Spain and Greece, where the situation has become dramatic. During 2003-2008, in most countries the trend has been to increase the number of employees in service and the most significant increase was in Bulgaria that in 2008 were employed in services with $45.62 \%$ more than in 2003. Also significant increases were registered in Lithuania and Hungary.

The economic crisis has strong influences started after 2008 in the number of people employed in services. However, they are different from country to country. At EU28 level the recession was impressive for service sector only in 2009 , when the number of employees in services decreased by $3.6 \%$, after which there is a slight recovery, the pace becomes slightly positive. Different situations are registered in Bulgaria, Greece and Romania. Thus, in Bulgaria in the early years of the crisis the number of employees in services continued to grow led by strong coastal development services and in ski resorts. The economic crisis in Europe has spread but here, in 2012 bringing the layoff of employees in services. In Romania, the impact of the economic crisis on services remained three years with significant reduction of employees in this sector. Recovery feels only in 2012 the demand for labor in the service starts to grow. Consequently, in Romania, service industries have not yet overcome the economic crisis.

\section{References}

Cristureanu, C. (2004). Economia invizibilului. Tranzacţiile internaţionale cu servicii.

Bucureşti: Ed. All Beck.

Ecalle, F. (1989). L'economie des services. Paris: Press Universitaires de France.

Ghibuţiu, A. (2000). Serviciile şi dezvoltarea. Bucureşti: Ed. Expert.

Gogonea, R.M. (2006). Statistica. Metode si tehnici aplicate in turism. Bucuresti: Editura Universitara.

Ioncică, M. (2000). Economia Serviciilor. Bucureşti: Ed. Uranus.

Labăr, A.V. (2008). SPSS pentru ştiinţele educaţiei. Bucureşti: Editura POLIROM. 
Lovelok, C.H. (1983). Clasifing Services to Gain Strategic Marketing Insights. Journal of Marketing, 47, 9-20.

Marelli, E., \& Signorelli, M. (2010). Employment, productivity and models of growth in the EU. International Journal of Manpower, 31(7), 732-754. doi:10.1108/01437721011081572

Stiglitz, J.E. (2008). Mecanismele globalizării. Iaşi: Ed. Plirom.

Tordjman, A. (1987). Strategies de concurrence dans le commerce: Les services aux consummateur. Paris: Les Editions d'Organisation.

Young, L. (2008). From Products to Services: Insight and Experience from Companies Which Have Embraced the Service Economy. England: Jon Wiley\&Sons Ltd..

Zaharia, M.R.M., \& Gogonea, R.M. (2008). Econometrie. Elemente fundamentale. Bucureşti: Editura Universitară.

Retrieved from

http://epp.eurostat.ec.europa.eu/portal/page/portal/statistics/search database 2014 Mar 17. 